\title{
Under Her Hat: Glimpses of Bonnet View
}

\begin{abstract}
The paper introduces the concept of tableau as articulated by film history and theory, with examples from the films of Roy Andersson, Jean-Luc Godard and Lars von Trier. A lesser known tradition, the bonnet view originates from Kelly Reichardt's western Meek's Cutoff which set out to tell the story from "the point of view of the woman who pours John Wayne's coffee." By replacing generic conventions, notably the customary widescreen with a square-like image, Meek's Cutoff conveys the visual and social restrictions signified by women's bonnets. The bonnet view is further traced in the tableaus of TV-series Handmaid's Tale and other cinematic portrayals of women's history (Jessica Hausner's Amor Fou and Carl Th. Dreyer's The Day of Wrath), exploring its potential as a vehicle of the female gaze.
\end{abstract}


* Scandinavian Division, Faculty of Humanities and Social Sciences, University of Zagreb Ivana Lučića 3, 10000 Zagreb

e-mail: jtomic@ffzg.hr 


\section{The bonnet view: Tableaus of history and cinema}

In film history the still image, and more particularly tableau, implies a disruption of the narrative, defamiliarisation, "[painting as cinema's] forbidden object of desire" (Dalle Vacche 1996: 1). Film is a medium of the present, generating an illusion of life, whereas the stilled image in contrast signifies past and death (for Kracauer, Sontag, Barthes, Bazin, Michelson, etc.). In Laura Mulvey's words: "While movement tends to assert the presence of continuous «now », the stillness brings a resonance of «then» to the surface" (Mulvey 2006: 13).

Tableau, defined as a scene or sequence filmed frontally in a single static and distant shot, dominated early cinema as a residue of other art forms, theatre and painting. ${ }^{1}$ Since then its status of "primitive" or later avant-garde otherness would haunt film theory, for example, in Stephen Heath's Narrative Space: "the tableau space of the early films is intolerable in its particular fixity, must be broken up in the interests of the unity of action and place and subject view (86). Film works at a loss, the loss of the divisions, the discontinuities, the absences that structure it. [...] The sequence-shot-with-deep-focus long take functions as a Utopia in this context - the ideal of a kind of «full angle», without prejudices, but hence too without cinema [...] «plus de cinema»" (Heath 1976: 91).

One of the few auteurs who has consistently worked with the tableau image is the Swedish director Roy Andersson (to the point that the Jury in Cannes commented that his films should be displayed at a photography festival rather than a film festival) (Tapper 2000: 72; Ode 2009: 3). His critically acclaimed "Living trilogy" (consisting of Songs from the Second Floor (2000), You, the Living (2007) and A Pigeon Sat on a Branch Reflecting on Existence from 2014), as well as his short films and the last feature film About Endlessness (2019), share a distinctive style. In fact, it could be said that they comprise one larger whole or cinematic work. Namely, they each consist of a paratactic structure of autonomous images (for example, just 46 shots in the feature film Songs from the Second Floor), with an elaborate mise-en-scène

Tableau (picture, image) in theatre, photography, cinema, and other arts shares the same connotations of an image emancipated from the narrative as well as hybridity of artistic codes. Tableaux vivants, "live" reconstructions of paintings, have a theatre history from e.g. Diderot's dramatic tableau that interrupted or ideally replaced the narrative sequence (e.g. Peucker 1995: 26f). "Tableau photography" is likewise a "staged" photography (implying both theatricality and quotations of popular film stills), which entails a shift from the diachronic sequence to the synchrony of an image (Campany 2007: 14f). 
modelled on the history of painting, especially expressionist. The overall stillness is achieved both by the static quality of the shot (both of the camera and lack of any movement within the frame), as well as repetitive, uniform interiors, buildings and street views, adding up to a polyptych of an apocalyptic city. The mise-en-scene is furthermore an anachronism, a pastiche of dystopian urban imagery, Scandinavian seventies etc. in what was often interpreted as the millennial present which got frozen in the record years of the welfare state and lives in the ruins of the utopian project (Brodén 2010: 37; see also Tomić 2014). Andersson further stretches his kaleidoscope of modernity to include surreal scenes of businessmen walking the streets as flagellants or otherwise searching for a solution to capitalist nightmare in, for example, a crystal ball, as well as a tableaux vivant reconstructing a WW2 photograph of an execution by the Nazis.

And it is (paradoxically) the stilled time that enables him to narrate this microcosm (a filmic equivalent of Borges's Aleph) of the present inhabited by the spectres of history. As Raymond Bellour claimed: "As soon as you stop the cinema, you begin to add time to the image. You start to reflect differently on film, on cinema" (see in Mulvey 2006: 186). For Roland Barthes, the tableau is a "bieroglyph in which can be read at a single glance the present, the past, and the future; that is, the historical meaning of the represented action" (Barthes 1977: 73). Even more idiosyncratically, Andersson's stylized tableaus are so constructed to accentuate the depth of field, using mirrors or painted scenography (even trompe l'oeil) to produce a Mannerist effect or a Deleuzian "unbridled depth [which] is of time and no longer of space" (Deleuze 1989: 108). "This is a function of depth of field: to explore each time a region of past, a continuum" (106), "depth of field creates a certain type of direct timeimage that can be defined by memory, virtual regions of past, the aspects of each region. This would be less a function of reality than a function of remembering, or temporalization: not exactly a recollection but «an invitation to recollect...»" (109).

Andersson himself elaborates on his tableau aesthetics by drawing on film theories of, for example, Andre Bazin who preferred this type of image to classical editing as it implies a more active mental state of the viewer, instead of directing one's attention into simply following the narrative logic unambiguously. Similarly, Andersson's reflection of his "complex images" (as he dubbed them) echo the writings of Noël Burch on acentric or centrifugal quality of tableau, with the entire frame as the possible playing area, and without hierarchy between the layers of an image. Such an image calls again for an active spectator, and invites multiple viewings, as if it was a painting. In this way the subject of labour appears - the material work needed to construct, for example, the tableaux of Songs from the Second Floor without digital technology, as well as the effort of the spectator to read layers of meaning.

\section{Art cinema of spectacle}

This issue of labour is addressed by Jean-Luc Godard's film Passion (1982) that follows director Jerzy (an exile from Poland) in his attempt to make a movie consisting of a series of tableaux vivants or re-enactments of Rembrandt's Night Watch, Goya's The Third of May and other classical paintings on the film set. Irritated by the disturbances from the outside world, such as the strike in the nearby factory and the constraints of commercial film industry (in particularly producers' repeated questions as to what exactly is the story of the film), Jerzy is a stubborn anachronism of film art. Fascinated by light and faces reminding him of the one 
in The Passion of Joan of Arc (La Passion de Jeanne d'Arc, 1928), he refuses to write the story for the film and dedicates himself instead to the passionate construction of his tableaux.

After Passion, Godard released Scenario for the film Passion (1982), a video documentary about the making of the film which opens and closes with the words travaille (work) and cinema written on the screen. Scenes of work from the film Passion and directorial work are showed in multiple exposition, as Godard tries to translate the concept of film or artwork into the language of video art and new media. One of the implications is the resemantisation of the film tableau with the advent of video and nowadays electronic or digital viewing where - as Mulvey says, the (static) image is easily accessible (and "the new technology [she adds optimistically] can make critics of us all." $)^{2}$

But what really became of the tableau and the work that makes it, both in its physical, material aspect as well as the pensive spectator in today's cinema practice? "As Pascal Bonitzer noted back in 1985, the plastic value of the shot and its propinquity to painting have been reinforced by the impact of the over-constructed images of music video clips, advertisement and the new digital images" (Vidal 2012: 115). Relying heavily on the tableau aesthetics, Lars von Trier's recent films are a case in point, even though their radical parody is seldom appreciated.

Trier's venture into disaster film, Melancholia (2011) is a story about a depressed bride that has a premonition of the end of the world which becomes real when the planet Melancholia hits the Earth. The musical score featuring Wagner's opera is one of the many references to romanticism that inspired Colin MacCabe to interpret the film as an example of pathetic fallacy, an illusion of a melancholic (in this case) that anticipates destruction as an extension of its own spleen. This solipsistic subjectivity that the film communicates is the one of the protagonist Justine who is an ingenious art director (or a copywriter) in an advertising agency, so throughout the film the spectator is exposed to attractive images to a level of oversaturation or kitsch. Tableaux vivants evoking popular scenes from art history show, for example, the protagonist as Millais' Ophelia or the film's crew staging The Last Supper, imitating tableau photographs widely used in advertising. ${ }^{3}$ Dystopian in a different sense to Andersson's, this fictional world is constructed (and self-destructed) as a series of visual attractions, reflecting on the crisis of storytelling and the dominance of the cinema (TV series, media) of spectacle.

Trier's last two films, Nymphomaniac (2013) and The House that Jack Built (2018), continue to develop this sadomasochist play with the art cinema audience, using sensationalist genres (pornography and slasher film) to structure the film as a chain of attractions of sex and/or violence, each then motivating absurdly pretentious parables on art history and aesthetics. The protagonist of The House That Jack Built, a failed architect, although identified in these parables with a series of artistic geniuses, is unable to build his own house. Instead, he produces grotesque sculptures and images made of human corpses, ultimately building

2 "Bellour's concept of the pensive spectator anticipated the thoughtful reflection on the film image that is now possible, a way of seeing into the screen's images, shifting them and stretching them into new dimensions of time and space [rescuing] those aspects of the cinema that Roland Barthes felt were lacking in comparison to the complexity of the photograph" (Mulvey 2006: 194).

3 Even more explicitly than Melancholia, Trier's next feature (Nymphomaniac) lays bare the process of merging the film with an advertising campaign which was itself structured like a plot: it opened with an introductory ensemble tableau, followed by posters of individual actors, i.e. film stars' faces in close-up simulating sexual climax. The attractions, i.e. posters, were released successively, to be anticipated like film sequels. See Tomić 2015. 
one such tableau "vivant" in the shape of the house, packed with high-culture references in a piece of art as infantile (cruel, banal) and random as the title of the film. ${ }^{4}$ As punishment, towards the end of the film he is frozen in a tableau vivant depicting Delacroix's The Barque of Dante, following a few other arbitrary scenes or kitsch that Lars von Trier had used to build the image of hell with.

This also brings to mind Peter Greenaway's reflections on intermediality from an interview he gave in 1999. A filmmaker whose work is synonymous with intermediality and cinematic tableaux, Greenaway was trained as a painter, but is also a curator of exhibitions, an installation artist, and a director of films that thematise painting, literature, photography, (landscape) architecture, dance, etc. But Greenaway rejected intermediality as an etiquette for his work since for him it carries connotations of propaganda and servitude to cultural politics. He used the example of Gianlorenzo Bernini, a Baroque sculptor and architect who combined different forms of arts to produce multisensory experiences, with a clear political aim to promote at the time increasingly unpopular Catholicism. Greenaway compared today's commercial Hollywood film to Berninian type of intermediality - a symptom of today's "spectacular cinema when it masks the crisis of the metanarratives" (see Oosterling 2003: 30).

\section{The bonnet view}

At the same time, other, lesser known histories of cinematic tableau remain to be reconstructed, and the following examples propose one such strand. They combine the trope of the nightmare of history and the feminist critique of it, with the most recent addition being the TV-series The Handmaid's Tale (2017). Based on Margaret Atwood's 1985 eponymous novel, the story is in tune with the recent surge of speculative fiction that projects post-apocalyptic scenarios of totalitarian regimes directing intimacy and reproductive rights, such as the movie The Lobster (2015, dir. Yorgos Lanthimos) or Ninni Holmqvist's novel The Unit (Enhet, 2009). The Handmaid's Tale is likewise set in a dystopian future, the ultra-conservative state of Gilead where women are reduced to being "two-legged wombs." Frequent flashbacks portray the heroine leading a normal life by, for example, showing her working or jogging through the city to the sound of Peaches' song Fuck the pain away ("IUD [Intra Uterine Device] SIS, stay in school, cause it's the best"). This structural contrast around which both Atwood's book and the series are built on is underscored by marked stylistic divide between what the film crew referred to as the realism of the "cinéma vérité style of flashbacks" versus the nightmarish vision of Gilead, portrayed in stylized "tableau-like compositions."

Although Zeitgeist readings of the novel and series found reflection on, for example, the Reagan or Trump politics, Atwood insisted on the universality of the mechanisms of Gilead's structural violence, repeatedly stressing that it was a pastiche, with a rich subtext of both fact and fiction. The tableaus of Gilead on the one hand evoke historical imagery, sourced none the least from art history; as the heroine describes her subjugation: "We must look good from a distance: picturesque, like Dutch milkmaids on a wallpaper frieze... or anything that repeats itself with at least minimum grace and without variation. Soothing to the eye, the

4 The House that Jack Built is a title of a nursery rhyme which seems like an epitome of distraction, piling up scenes in and around the house which tell nothing about Jack building the house.

5 https://www.indiewire.com/2017/06/handmaids-tale-reed-morano-cinematography-1201845595/ [access: 7.07.2020]. 
eyes, the Eyes, for that's who this show is for" (Atwood 1986: 275). The truncated vision is at the same time meant to illustrate the subjective perspective of the heroine, shaped by the white bonnet that often dominates the screen, partly obscuring the visual field. This has been called a "bonnet view": a metaphor for radically blinkered, tunnel vision of the world which lacks peripheral vision or context, i.e., which is isolated and frightening. ${ }^{6}$ Unlike Andersson's tableaus, Gilead scenery offers no "anarchy" and acentric quality of the primitive tableau; its minimalist, barren sights are purified of excess content, and the spectator's attention is unequivocally directed to a specific part of the image (for example, by diagonal staging, with rare silhouettes hanging at the background of the grey execution wall). The spectator is sutured to this experience, both by the predominant close-up shots of the heroine's face and torment, as by the oversized bonnet that limits and directs vision, offering no lines of escape from the cloistered and claustrophobic world of Gilead.

The term "bonnet view" in this sense of the narrowed-down vision of the subject (or object) that is forbidden any access to the political sphere or the public domain was originally used by the US director Kelly Reichardt in relation to her film Meek's Cutoff (2010). Commonly described as an "anti-Western" or "feminist Western", the film set out to tell the story, in the director's own words, "from the point of view of the woman who pours John Wayne's coffee" (see White 2016: 220). Reichardt uses the iconography of the Western as the American history's foundation myth to tell a somewhat different story of a pilgrims' trail across the Oregon desert in the mid- $19^{\text {th }}$ century. Unlike the white females representing the home in the code of the Western, i.e., archetypically waiting on the porch of a little house on the prairie, Reichardt's women are on the road, very much involved in the dirty business of traveling. Based on female travellers' diaries, the film replaces the action laden scenes and suspense of the Western with a list of chores, trance-like drudgery of the daily work, moving across the monotonous landscape in what is by now a canonical example of slow cinema. The story is furthermore focalized through the perspective of one of the expedition's wives Emily, as is suggested by, among others, the film's obsessive framing (bonnets or similar frames, for example, those of waggon arches) (White 2016:217f). Most notably, the usual 1.85:1 widescreen format has been reduced to a square-like (4:3) aspect ratio, cutting the edges of the frame, in marked contrast with the epic scope and open spaces typical for the Western. As a result, instead of romanticising the West, the effect is that of a "bonnet view" that reflects the limited and disoriented perspective of women who have no knowledge of geography of the route they are taking or any authority to decide on one. ("We used the real size ones and they come out a foot on either side," said Reichardt; see Hall 2014: 122). ${ }^{7}$ A significant item of the miseen-scene, the pioneer women's bonnets are playfully used and inscribed with meaning, and ultimately raised to a symbol of the visual and social restrictions (with one such item lying in the dust appearing as a sole motif on the film's poster). The pregnant Mrs White, for example, nearly loses hers to a gust of wind, but she turns back into the wind to retrieve it, finally

6 https://www.buzzfeednews.com/article/annehelenpetersen/blessed-be-the-fruit [access: 7.07.2020].

7 It is not just the truncated space that contributes to the "opacity and non-knowledge central to this film" (Gorfinkel 2015: 129): the speech is often silenced, for example, when the men are having a conversation in the distance. The viewers are sharing the perspective of the women who are left outside of men's decision-making and can hardly hear them. Furthermore, women's speech is of second-rate, an echo of men's, as a large portion of their talk is about retelling or trying to understand the men's words and directions. Additionally, the barely visible night scenes, shot only under low lamplight and firelight, further challenge the spectator's insight (see also Tomić 2017). 
snatching it just before it had the chance of disappearing beyond the wall-like frame of the tableau. (The scene also brings to mind a classic feminist take on the Western genre, Lilian Gish's and Victor Sjöström's The Wind from 1928; see White 224).

Another example of the bonnet view as an experience of being trapped in a period piece can be seen in Jessica Hausner's film Amor Fou (2014). The extreme flatness of space (at times it seems to be a film about wallpaper) become an imprint of a historical landscape that constrains the individuals who are again unable to transcend it. In a style that resembles the camerawork in Stanley Kubrick's historical drama Barry Lyndon (1975), depthless bourgeois interiors where actors and objects are immobile are not only visually modelled on paintings but the camera treats them as tableaus, exploring them as two-dimensional surfaces, rarely cutting the scene by employing the shot/reverse-shot pattern. ${ }^{8}$ The ideal of romantic love that the heroine naively nourishes, only to become a victim of masculine violence in the face of looming social change and uncertainty, "bears the imprint of a historical landscape" that defines the individual hero's path. As it was said of Barry Lyndon, the tableaus unveil the extent to which "[the character's] trajectory is not individual and romantic, but dependant on a broader movement, both historical and social, [which] becomes the true subject of the film." (Vidal 2012: 114)

Finally, a radically subversive articulation of the bonnet view can be found in an earlier artwork, the film Day of Wrath (1943) by the Danish director Carl Theodor Dreyer. Dreyer's oeuvre typically features female characters accused of witchcraft or otherwise victimized by narrow-minded, patriarchal communities, using a rich subtext of different arts, especially painting, to illustrate the historical setting. Day of Wrath is no exception, and the fact that it was filmed during the Nazi occupation of Denmark in WW2 (and widely read as an act of resistance), gave an additional layer to the nightmare of history it portrayed.

Set amidst the witch-hunts of the $17^{\text {th }}$ century, Day of Wrath is a diptych featuring an old woman, burned at the stake, and a young pastor's wife Anne, who proves to be her mirror image as she falls in love with the pastor's son and is accused of witchcraft. The film is on the one hand full of visual citations; as the film critic and art historian Brigitte Peucker summed up:

In Day of Wrath, Dreyer makes frequent use of tableau scenes in which movement is deliberate and kept to a minimum, giving the effect of period vignettes frozen in time, like painting. The spaces of film and their visual composition have been compared to the paintings of Vermeer and, as Kracauer puts it, other "Dutch masters brought to life"; in more than one scene the configuration of the village notables strongly evokes the group portraits of Frans Hals. (95)

Or, in the playful words of avant-garde filmmaker Stan Brakhage:

It is in his Day of Wrath - each scene of it shot in blatant imitation of Dutch "religious" and "genre" painting... from Rembrandt to the worst of them - he chased his 17th century Danish witches through a veritable museum of black \& white Holland art... a mise en scène that said "art-art-ART" at every camera turn — and burned this "Dies Irae" witch at a protestant stake [...] these scenes of religious "quackery" occur in the chiaroscuro of Rembrandt's and Vermeer's domain - and are thus composed of painterly sacredness. ${ }^{9}$

8 The social scenes evoke the landscapes in eighteenth-century British painting (reminiscent of Thomas Gainsborough, Joshua Reynolds, William Hogarth, etc.) (Vidal 2012: 113).

9 Brakhage goes on to reflect on the subversive dimension of this work of Dreyer, better known as art cinema's master stylist: 
At the same time, it is the film that makes the subject out of female gazing or glancing, first under the bonnet and gradually casting it off (to reveal Anne's unruly hair, a symbol of awakened sexuality, filmed as an intrusion or a rupture in the historical canvass) (e.g. Kracauer 1971: 90f; Bordwell 1981: 120f). The possibility of a female gaze is suggested by a series of devices: the narrative is structured around a repeated scene of the heroine looking through window frames and rare POV shots that follow. Her large expressive eyes are a topic of men's misled projections, examining conflicting definitions of her vision. The camera in the film is said to imitate the movements of Anne's body (Peucker 1995: 97), suggesting, as it is characteristic for Dreyer, the existence of another spatio-temporal logic or even subjectivity or "soul" (Dreyer and Skoller 1973: 122, 175f). ${ }^{10}$ A work of Dreyer's poetic mastery that attributed the film medium with a unique access to the physical world or its "truth", Day of Wrath is juxtaposing the practice of seeing with the historical discourse - the written word, the records of witch trials, as well as the tableaus of art history - that it redefines. ${ }^{11}$

\section{Conclusion}

With the advent of digital technology and the changing media landscape, artists like Lars von Trier or Peter Greenway questioned the subversiveness and high art pretensions of what is predominantnly an attraction or spectacle of tableau photography and cinema. Nothwitstanding the residual form of tableau-image in the works of authors like Roy Andersson, the oppositional history (Bordwell, 2005) of cinematic tableau is therefore changing in both film practice and theory. What this paper proposes is a microhistory of cinematic tableau, a feminist strand whose contours can already be traced in theoretical accounts of "the bonnet view". Stylized tableaus framed by the female bonnets critically portray repressive social orders, using the codes of the western (Meek's Cutoff), $17^{\text {th }}$ century Dutch (protestant) painting (Day of Wrath, Handmaid's Tale) or other period pieces (Amour fou, etc.) Further research might reveal more radical poetics such as Carl Theodor Dreyer's films that envisioned the potential of film image to rewrite the tableaus of history.

[he exposed] the whole paint pot as the trap, of sensibility, it is as sure as church: (you have but to look at the 'stills' of this film, and remember that Carl's an original man), to realize the terrible parody going-on herein: (yet if none have so-seen this film's nursery pun upon Art it is because all eyes of this Time are so-trapped in it/Art-as-church).

Much has been written about Dreyer's camerawork, and its replacement of functional tracking shots or pans with, what has been called by, for example, his cameraman Henning Bendtsen, "expressive camera", an element of what Paul Schrader described as a "transcendental style" or, in David Bordwell's condensed remark: "We are watching the story unfold, and suddenly we are not watching it anymore; the style flings us into spatial and temporal processes that engage our perception for their own sakes" (6).

11 In his seminal essay Thoughts on My Metier (aka A little on Film Style) he describes the ideas behind Day of Wrath:

We hope that the film will set ajar for us a door into these other worlds [...] We forced ourselves to search for truthfulness. [...] The tension lies beneath the surface and releases itself the day the catastrophe takes place. It is that latent tension, that smouldering discomfort behind the minister's family's everyday life that I have so urgently been trying to bring forward. (Dreyer and Skoller 1973: 134) 


\section{Bibliography}

Andersson Roy (2009), Vär tids rädsla för allvar, Studio 24, Stockholm.

Atwood Margaret (1986), The Handmaid's Tale, Ballantine Books, New York.

Barthes Roland (1977), Image-Music-Text, Fontana, London.

- (1980), Camera Lucida, Hill and Wang, New York.

Bazin André (2009), Šta je film? (I-IV), YU FILM DANAS XXII no 1-2 (90/91), Novi Sad: $3 \mathrm{D}+$.

Bellour Raymond (1990), The Film Stilled, "Camera Obscura”, vol. 8 (23-24).

Bordwell David (1981), The Films of Carl-Theodor Dreyer, University of California Press, Berkeley.

- (2005), O povijesti filmskoga stila, HFS, Zagreb.

Brakhage Stan (1972), The Brakhage Lectures: George Méliès, David Wark Griffith, Carl Theodore Dreyer, Sergei Eisenstein, The Goodlio, Chicago.

Brodén Danie (2010), Vad är det som har hänt? Om Roy Andersson och den urspårade välfärdsstaten [in:] Motsträviga synsätt: om rörliga bilder som bjuder motstånd, eds. Rönnberg M., Westling K., Filmförlaget, Visby.

Burch Noël (1991), In and out of Synch. The Awakening of a Cine-dreamer, Scolar Press, Aldershot, England.

Campany David (2008), Photography and Cinema (Exposures), Reaktion Books, London.

Dalle Vacche Angela (1996), Cinema and painting: how art is used in film, University of Texas Press, Austin.

Deleuze Gilles (1989), Cinema 2: The Time-Image, The Athlone Press, London - New York.

Dreyer Carl Theodor, Skoller Donald (1973), Dreyer in Double Reflection Translation of Carl Th. Dreyer's Writings about the Film, Da Capo, New York.

Gorfinkel Elena (2015), Exhausted Drift: Austerity, Dispossession and the Politics of Slow in Kelly Reichardt's Meek's Cutoff [in:] Slow Cinema, eds. Luca T. de, Barrados J.N., Edinburgh UP, Edinburgh.

Hall Dawn (2014), American Independent Female Filmmakers: Kelly Reichardt in Focus, ProQuest, UMI Dissertations Publishing, Ann Arbor.

Heath Stephen (1976), Narrative Space, "Screen”, vol. 17, issue 3.

Kracauer Siegfried (1971), Priroda filma I, Institut za film, Beograd.

- (1995), The Mass Ornament: Weimar Essays, Harvard UP, Cambridge MA.

MacCabe Colin (2011), Riviera Eschatology, "Film Quarterly", vol. 651.

Michelson Annette (2003), Filosofska igračka, Samizdat B92, Beograd.

Mulvey Laura (2006), Death $24 x$ a Second: Stillness and the Moving Image, Reaktion Books, London.

Ode François (2009), 5 x Roy Andersson, Studio 24, Stockholm.

Oosterling Henk (2003), Sens(a)ble Intermediality and Interesse Towards an Ontology of the In Between, "Intermedialities", vol. 1.

Peucker Brigitte (1995), Incorporating images: film and the rival arts, Princeton UP, Princeton N.J. Sontag Susan (1982), Eseji o fotografiji, SIC, Beograd.

Tapper Michael (2000), Folkhemmets svanesaing: Michael Tapper intervjuar Roy Andersson, "Filmhäftet", vol. 28, 111/3. 
Tomić Janica (2014), "Tablo" i fllmska slika Roya Anderssona, "Književna smotra: časopis za svjetsku književnost”, vol. 127 (2).

- (2015), Živa slika - film, "Kazalište: časopis za kazališnu umjetnost”, vol. 59/60.

- (2017), Pogled ispod oboda, "Filmonaut", vol. 17/1.

Vidal Belén (2012), Figuring the Past, Period Film and the Mannerist Aesthetic, Amsterdam UP. White Patricia (2016), Pink Material: White Womanhood and the Colonial Imaginary of World Cinema Authorship [in:] Routledge Companion to Gender and Cinema, eds. Hole K., Jelaca D., Kaplan E.A., Petro P., Routledge, London. 